\title{
Role of Effective Internal Control Structure in Achievement of Targeted Success in Businesses
}

\author{
Prof. Dr. Hasan Turedi \\ Dr. Duygu Celayir \\ Istanbul Commerce University, \\ Department of Accounting and Auditing, Turkey
}

Doi: 10.19044/esj.2018.v14n1p1 URL:http://dx.doi.org/10.19044/esj.2018.v14n1p1

\begin{abstract}
Due to economic relations evolving over time, technology and changing business environments, the way in which one of the management functions, "control", is executed has undergone a number of changes. Accordingly, the management of a business has become unable to control operations directly, making it a necessity for businesses to obtain timely and reliable data for a number of purposes, including protecting assets, and eliminating or minimizing errors and frauds. Internal control structures, formed within the business to serve this purpose, have become more relevant in terms of protecting business assets, identifying the way operations are executed and ensuring execution of operations at the desired level of efficiency. Internal control is defined as a structure in businesses which is directed by board of directors, managers and employees, aims to ensure effectiveness and efficiency of operations, reliability of the financial reporting system, and compliance with laws, and is designed to provide reasonable assurance in these aims.

Depending on the position they assume, officials at every level have responsibilities in the context of ensuring effective and efficient execution of the internal control structure in businesses, and accordingly, of corporate management, and attaining expected goals. This study will examine development of an effective internal control structure in terms of attaining expected success by businesses and the impact thereof on the business.
\end{abstract}

Keywords: Internal Control, Internal Control Structure, Targeted Success

\section{Introduction}

Of the workfield standards, which are listed among generally accepted auditing standards, the second one requires review of internal control structure of businesses and recognition thereof as a whole. 
In this context, the auditor must study the internal control structure of the business and provide reliable information. Reliability of the information provided depends on how well-organized an internal control structure in a business is and how constantly its operation is supervised. In other words, an effectively and efficiently executed/implemented internal control structure in a business may be considered direct audit evidence.

Responsibility to establish and implement the internal control structure rests with the management of the business.

Review/evaluation of the internal control structure by an independent auditor is highly critical in terms of collecting audit evidence in sufficient number and at sufficient quality at the audit planning stage.

That is because reliability of the internal control structure in place at a business will have direct impact on quantity and quality of audit evidence to be collected.

Reviewing the internal control structure at the planning stage and finding it to be reliable will have direct impact on audit implementation time and the work to be used/benefited from. If the internal control structure is implemented as effectively and efficiently as planned, this may lead the audit team to keep the scope narrower and to minimize implementation time. A well-functioning internal control structure does not require a high number of evidences, lowering the number of auditor assistants required in an audit team. This saves on costs, and gives the auditor and team members more time to work on other audits.

Effective and efficient execution of the internal control structure includes protection of assets, timely and accurate entry of accounting information on the accounting environment, easy access to information whenever desired (obtaining accurate information), ensuring compliance with agreed accounting policies, and directing all business activities in line with the goals.

When the auditor evaluates (reviews) the internal control structure, they will see closely how all these operations are executed and have the opportunity to decide on the quantity and appropriateness of the evidences to be collected.

In reviewing the internal control structure, the independent auditor will attain reliable information on accuracy of the accounts kept at the business, the financial statements developed, and the accounting policies put in place. This way, necessary and useful information is also attained on the scope, types, level of detail and implementation time of the audits, particularly those to be carried out at year-end. Ultimately, the auditor will provide suggestions to relevant business managements on correction of identified internal control deficiencies (Türedi, 2013). 


\section{Definition of Internal Control}

In Turkey, the concept of "control" is perceived to be close in meaning to, and used interchangeably with, the concepts of audit, inspection, revision and accounting auditing (Gürbüz, 1995; Türedi, 2007).

The accepted content and meaning of internal control in Turkey appear to have differences from its international meaning. The concept of "control" used in Turkey denotes the case in which a completed operation/transaction is reviewed and evaluated by an official (usually an auditor) for accuracy or compliance thereof with the legislation.

Internationally, "control" is rather considered an activity in closer proximity with the management concept and a part of the management process.

In other words; control is an activity covering the methods, operations and practices which are integrated into all processes involved in implementation/execution of an operation, rather than the one performed following implementation/completion of an operation as understood in Turkey. In this sense, controls have an element of continuity. And accordingly, not just managers and auditors, but all employees at a business are responsible for controls.

To summarize; the concept of control refers in Turkey to the control (review/evaluation) of a completed transaction or operation, coming to the understanding that those who execute an operation and those who control the result are different people.

Internationally, the concept of "control" is understood to be keeping under control, supervising, monitoring and evaluating all stages (the whole process) of an operation or practice (Özbek, 2012).

In accordance with the perception above, internal control may be defined as follows, within the framework of the Institute of Internal Auditors (IIA) standards and in accordance with the COSO internal control approach, which is the most generally-accepted approach in this field: model;

Internal control, according to COSO (COSO, 2004; IFAC, 2013)

Internal control is a structure affected by board of directors, senior management and other employees (staff) of an organization and created to provide a reasonable (limited) assurance as to performance of the following goals.

- $\quad$ Effectiveness and efficiency of operations,

- Reliability of financial statements (reports),

- $\quad$ Compliance with law and other legislation.

follows;

The Institute of Internal Auditors (IIA) defines internal control as 
"Control is the measures taken by management, the board and other parties to manage and identify risk and increase the likelihood that established objectives and goals will be achieved. Management plans, organises and directs the performance of sufficient actions to provide reasonable assurance that objectives and goals will be achieved"(IIA, 2004).

Reasonable assurance, deemed critical in audit efforts, may be defined as follows.

\section{Reasonable Assurance}

Collection of sufficient and appropriate audit evidence to reach the conclusion that financial statements as a whole are not misstated in quality or quantity. It is an assurance that is sufficient, but not exaggerated. In terms of reliability of the internal control, reasonable assurance is taken into account in every stage of the independent audit effort (SPK, S:X, N:22).

\section{Evolution of Internal Control}

A look at the historical evolution of internal control shows that the concept of "control" has evolved in tandem with the history of accounting and independent audit. However, it is the Anglo-Saxon countries which showed efforts/ developed regulations relating to evolution of this concept in the last century.

Differences exist between Anglo-Saxon and Continental European countries regarding the concept of control.

The first of these differences may be expressed as follows:

In Continental European countries, internal control is understood to be retrospective review/examination, i.e., control, of completed actions/operations; while the Anglo-Saxon understanding of internal control considers it as a process covering the whole of execution and implementation of an operation, in line with how the concept is understood today.

To summarize; the Continental Europe understands internal control (control) to be the control of completed/concluded operations, while the Anglo-Saxon approach sees it as a management activity aiming to keep the whole of an operation or process under control.

Economic policies implemented in Continental European countries are said to have impact on development of their understanding of control. The concept of control has differentiated as, particularly following the World War II, state-supported development and entrepreneurship activities had to be executed with a certain level of state support and planning, and planning results had to be controlled.

In this context, as economic activities in the Soviet Union and affiliated countries were executed with fully-centralized planning and completely independent of a free market mechanism, an effective inspection and control 
structure to retrospectively assess past operations and transactions had to be put in place so as to assess/provide follow-up of compliance with the plans.

In Turkey, deemed a Continental European country, similar practices were carried out both in the development activities carried out in the early Republic era and in the planned development periods post 1960s, and continuous controls were put in place to assess consequences of the plans and activities. Consequently, both in Turkey and in other countries where the state is the main driver / heavily involved in economic activities (despite the gradually decreasing involvement of the state), the concept of control has historically developed in such a way to be understood to denote retrospective control of completed operations.

The second difference relates to the fact that the concept of control in Continental European countries developed under influence of public administration (as the state was heavily involved in the economic order), and in the Anglo-Saxon countries, it developed in the context of existence of the free market order, capital and share ownership, protection of the investor and disclosure of financial statements.

In EU countries, internal control developed with corporate management regulations. As of 1990s, various European countries introduced the kind of corporate management principles which are understood to place great importance on development on an effective internal control structure, board of directors, roles and responsibilities of senior management.

With respect to the concept of internal control, EU countries appear to have been affected from the developments in US, and their perceptions in terms of definition and scope of internal control appear aligned with one another (Özbek, 2012).

In "Changing Audit Objectives and Techniques" (1962), R. Gene Brown provides the following table as to evolution of (the concept of) internal control.

\begin{tabular}{|c|c|c|c|}
\hline Period & Stated Audit Objectives & $\begin{array}{c}\text { Extent of } \\
\text { Verification }\end{array}$ & $\begin{array}{c}\text { Importance of } \\
\text { Internal Controls }\end{array}$ \\
\hline Ancient -1500 & Detection of fraud & Detailed & Not recognized \\
\hline $1500-1850$ & Detection of fraud & Detailed & Not recognized \\
\hline $1850-1905$ & $\begin{array}{c}\text { Detection of fraud, and } \\
\text { Detection of clerical error }\end{array}$ & $\begin{array}{c}\text { Some tests, } \\
\text { Primarily Detailed }\end{array}$ & Not recognized \\
\hline $1905-1933$ & $\begin{array}{c}\text { Determination of fairness of } \\
\text { reported financial position } \\
\text { Detection of fraud \& errors }\end{array}$ & Detailed and Testing & $\begin{array}{c}\text { Slight recognition } \\
\text { Increased awareness }\end{array}$ \\
\hline $1933-1940$ & $\begin{array}{c}\text { Determination of fairness of } \\
\text { reported financial position, } \\
\text { Detection of fraud \& errors }\end{array}$ & Detailed and Testing & Awakening of interest \\
\hline $1940-1960$ & $\begin{array}{c}\text { Determination of fairness of } \\
\text { reported financial position }\end{array}$ & Detailed and Testing & Substantial emphasis \\
\hline
\end{tabular}


A study of the table of internal control's historic evolution reveals that internal control practices were rather carried out to detect frauds and that these practices were maintained by 1850 s. From 1850 s until 1900 , it is noted that effort was made to detect clerical errors.

Internal control regulations (developments) in US arose from the need that emerged following a number of key financial troubles.

The most notable example is the 2002 "Sarbanes Oxley" Act, enacted following financial depressions such as Enron and World Com.

The Act was a response to such issues and had key global consequences. In the similar vein, the COSO (the Committee of Sponsoring Organizations) model, which is the most generally-accepted internal control model today, is deemed the basis model for all internal control regulations and standards across the world today, particularly in EU countries and including international organizations, although it was originally developed in US to prevent development of misleading financial statements.

Today, a key aspect of internal control is that it is an activity (function) of the management itself, rather than that of the staff tasked with control duties.

Since 1920s, it has been discussed that the internal control structure is closely related to the audit work by independent auditors.

In accordance with this understanding, which is accepted today as well, existence of a well-functioning internal control structure not only narrows the scope of audit efforts by independent auditor (review of financial statements), but also shortens audit time.

Review of all documents and transactions for independent audit purposes is known to increase the costs immensely, particularly for business performing transactions in large volumes and numbers. On the other hand, development of a well-organized and effectively-implemented internal control structure (system) will relieve the independent auditor from the need to perform very detailed examinations, making it possible to save on costs and time.

The Special Report in Internal Control, issued in 1948 by the American Institute of Accountants (AIA) provided the first official definition of internal control.

Acting on the definition above;

Internal control includes all measures accepted and implemented to protect the organizational plan and assets, ensure accuracy and reliability of accounting information, improve efficiency of operations, and promote adherence to management policies determined (Güredin, 2010).

In accordance with AIA's 1948 special report, a more understandable definition of internal control can be made as follows: 
Internal control includes all measures and activities accepted and put in place to protect the organizational plan and assets of the business, ensure accuracy and reliability of accounting information (data), develop efficiency of operations, and promote adherence to (compliance with) corporate policy arrangements.

The above-mentioned definition constitutes the essential definition of internal control today.

Renamed to American Institute of CPAs (AICPA), the American Institute of Accountants expressed in 1958 that internal controls should be divided into two, i.e. accounting control and managerial control.

Accounting controls covers all transactions, methods and operations directly related to the organizational plan, protection of assets, and reliability of accounting information (Melgs and Meigs, 1988).

Accounting controls denote control measures relating to authorization and approval, registration, development of financial statements, protection of assets, which should be explicitly separated from physical controls over assets and internal auditing duties (Güredin,2010).

In the context of separation of duties and accounting controls; it is highly critical to separate the duties of take-over, protection and registration of assets and to have them performed by different people.

Managerial controls cover all methods and transactions which are directly related to effectiveness of business operations and adherence to management policies, but indirectly related to financial records. Statistical analyses, movement and time studies, annual reports, staff training programs and controls such as quality control constitute managerial controls.

In the narrow sense, control only refers to accounting control, and only covers controls related to financial data and accounting transactions. Again in the narrow sense, internal control usually refers to accounting control (Gürbüz, 1995).

Whether managerial or accounting, all controls affecting accuracy and reliability of financial statements fall within the scope of interest of the independent auditor. Here, reliability of financial statements is the key factor. And it is accounting controls which have direct impact on reliability of financial statements (Güredin,2010).

In light of the descriptions above, a more easily understood definition of internal control may be as follows (Cook and Winkle, 1980):

Internal control structure is;

A structure covering the determination of roles and responsibilities, the organizational plan of the audited business, and the establishment of the measures, methods and actions as well as the accounting planning and reporting system so as to protect company assets, ensure accuracy and reliability of information and reporting 
relating to accounting and other activities, improve effectiveness and efficiency of business operations, and ensure adherence of business operations to the management-determined policies.

Turkish regulations define the internal control structure as follows (SPK, S:X, N:22):

"Internal control structure denotes the structure designed and implemented by the governance, management and other personnel to provide a reasonable assurance for compliance with laws and regulations when the business achieves its goals and operations and transactions are carried out effectively. To this end, the internal control structure is designed and implemented so as to lay out operation risks posing a thread in terms of achievement of such goals.

Internal control is a process implemented and maintained to provide reasonable assurance as to reliability of financial statements (reporting), effectiveness and efficiency of operations, and achievement of company goals with respect to compliance with applicable laws and regulations.

The auditor must have an adequate understanding of the accounting and internal control structure to plan the audit and perform an effective audit. The auditor must use professional judgment to identify the audit risk and set the audit actions and methods to minimize the audit risk to lowest acceptable level (ISA 315).

International Standards on Auditing (ISA 315) defines internal control as follows:

Internal control is a process designed, implemented and maintained by those charged with governance, management and other personnel toprovide reasonable assurance about the achievement of an entity'sobjectives with regard to reliability of financial reporting, effectivenessand efficiency of operations, and compliance with applicable laws and regulations (ISA 315).

\section{Purposes of Internal Control Structure}

Acting on the definitions relating to internal control, the purposes of internal control structure may be listed as follows (Türedi, 2007; Aksoy, 2007):

a) Protect business assets against all kinds of negative situations,

b) Ensure accuracy and reliability of any business-related information,

c) Ensure adherence of business operations to determine business policies, management plans, and the legislation,

d) Ensure economic, effective and efficient use of business resources,

e) Carry out obligations arising from accountability,

f) Continuously produce fiscal and management information, and disclose them full-time through regular reporting,

g) Ensure managerial control, 
h) Ensure accounting control,

Purposes of the internal control structure of businesses are summarized as follows (Homes and Overmyer, 1975);

- Protect assets,

- $\quad$ Protect against improper spending,

- $\quad$ Protect against improper funding and borrowing,

- Ensure reliability and accuracy of business and financial operations,

- Ensure effectiveness of the business,

- $\quad$ Ensure and measure adherence to established policies of the business.

Internal controls may be related to management or finance. Internal managerial controls cover the relationships and contacts established by sales staff of a business in the name of that business, the orders they receive, the returns, and the reasons thereof.

Financial controls cover the activities by the staff who will make payment or collection, and those who register money transactions into the accounting environment. Internal managerial controls and internal financial controls may often overlap.

These two internal control activities may not be separated by strict lines. All internal controls include all duties. However, business managements take internal financial controls into a deeper consideration. A complete internal financial control is achieved by assessing accuracy of the management's financial transactions and financial entries (registration into the accounting environment and compilation into financial statements).

Internal auditors are more interested in internal financial controls than internal managerial controls. Effective and efficient implementation of the internal financial control structure depends on the following requirements.

- $\quad$ Establish areas of responsibility,

- Good planning and good implementation of financial and accounting records,

- $\quad$ Effective separation of duties of the business' staff,

A good separation of duties will separate the financial roles and responsibilities of an employee from those of other employees. This way, each employee will work independently and hesitation in operations is eliminated, making it easier to perform work.

In terms of separation of duties, operations will be planned so as to ensure that no single employee has complete control over all stages of a work or operation. For instance; no single employee may have control over the whole of collections, payments, payrolls, expenses or sales operations. Performance of the work or operation by different people contributes significantly to avoidance of errors and frauds. Similarly, performance of accounting operations by people other than those performing the above will 
make accounting information, and accordingly financial statements, more reliable to users of this information.

Therefore, internal control is a function of the business administration. As businesses grow physically, as their operations grow, diversify, and become more sophisticated and as the types of transactions increase, so do the management's need for reliable information so as to protect assets, eliminate error, calculate income and assess established business policies and practices.

All these needs may only be satisfied by establishment of an effective internal control structure.

\section{Principles of Internal Financial Control Structure}

Internal control structure may vary across businesses. An effective internal financial control structure may only be developed by assigning and implementing roles and responsibilities. Key principles of an effective internal control structure as follows (Holmes and Overmyer, 1975):

- Responsibility should be determined for each role. Quality of the control decreases in case of improper assignment or non-determination of responsibility. For instance; if responsibility for collection affairs is not given to a specific staff, the likelihood of theft or disappearance of money from the cash register will increase.

- $\quad$ Accounting and financial affairs should be separated. If collection and payment activities or sales and collection activities are not separated, the assigned staff may embezzle a part of the collection or payment and make registrations to the accounting environment so as to disguise such embezzlement.

- No employee should have full authorization over all stages of a business operation. Any one may commit error, fraud, negligence, carelessness or mistake. If different employees are involved in specific stages of an operation/process, however, the likelihood that one of these employees will notice the mistake will increase unless they connive deliberately.

- $\quad$ To assure accuracy of accounting affairs and operations, a method should be put in place to assess accuracy. For instance; in businesses where retail method is applied, the total value/amount of daily sales must be compared with documentation/receipts of the goods sold.

- $\quad$ Assigned staff should be selected carefully, and trained with regular re-trainings.

- $\quad$ Employees should be bound with a contract. This serves as a deterrent for those who are psychologically ill-intentioned.

- If possible, schedule of the employees/assigned staff should be rotated. The roles filled by acting employees should not be kept vacant. 
- $\quad$ Change of roles from time to time will decrease likelihood of fraud, and ensure commitment to the role.

- For each position, a written instruction should be developed. Dissemination of handbooks for operations and controls will both ensure continuous learning and avoid misunderstanding from a single source.

- $\quad$ Protective benefit of the double-entry method in accounting should not be over-relied on. Double-entry practice may not replace control activities. Incorrect entries are hard to detect if double-entered.

- If possible, control accounts should not be overused. Use of control accounts by different people at different rules will help identify errors/frauds. - $\quad$ Accounting transactions and entries may use mechanical or electronic hardware. Even in these cases, attention should be paid to potential errors and frauds in accounts. Use of mechanical tools, however, will make internal control more effective as it will accelerate and make efforts easier.

\section{Reasons for Assessment of Internal Control Structure}

The independent auditor assesses (reviews) the internal control structure for a number of reasons. These are listed as follows.

- Determine, individually or collectively, and through footnotes and remarks, the level of risk materiality arising from unreconciled financial transaction accounts,

- Determine evidence collection techniques to be used in audit work,

- Identify level of reliability of the internal control structure, and accordingly determine type, quantity and quality of audit evidence to be collected,

- Determine whether or not the internal control structure has been implemented as effectively as planned,

- $\quad$ Provide evidence as to accuracy, reliability, verity and adequacy of transactions performed in the business,

- Determine level of detail of audit work,

- Assist with planning of audit schedule,

- $\quad$ Assist with planning of audit effort,

- Identify weaknesses of internal controls, and provide the management with suggestions to avoid these.

\section{Protect Business Assets}

Businesses are founded for a variety of purposes. While some are founded to be useful for the society through direct service, most are founded for profit through production of goods and services. Though indirectly, these serve the society, too. But the main purpose is to earn profit. Businesses maintain their operations by producing goods and services or through trading. 
No matter their type, businesses acquire various assets for the purpose of producing goods and services or trading.

These assets include;

a) Direct cash/monetary assets (money, cheque),

b) Various receivables (with or without note),

c) Tangible assets, such as fixtures, machinery, facilities, vehicles, buildings, land/plot,

d) Rights in the form of intangible assets, such as rights, goodwill, brands etc.

To attain their purposes, businesses must first protect these assets against all kinds of risks/negative situations.

These assets are always facing unwanted situations or risks.

Such risks include:

a) Theft, b) Breakage, c)Rust, d) Wastage, e)Outdatedness and obsoleteness, f) Depreciation, g) Earthquake, flood, fire etc.

Tangible assets may be depreciated or eliminated due to a number of factors including theft, rust, outdatedness, depreciation or obsoleteness.

Business managements take various measures for the purpose of preventing, eliminating or reducing such asset-related risks. It is the management's responsibility to develop a robust, well-executable and effective internal control system at the business so as to eliminate or reduce all such risks.

The following are the asset-related duties of a management:

a) Ensure timely delivery of orders,

b) Ensure conformity of ordered assets with received assets,

c) Receipt of assets and protection thereof at relevant places,

d) Enter purchases into inventory cards immediately, and place the same to relevant unit/shelves,

e) Communicate relevant information to the accounting immediately after the purchasing transaction (ensuring accounting entry),

f) Enter outflows to inventory cards immediately,

g) Prevent theft,

h) Assess the latest situation from inventory cards, and control the quality of assets,

i) Ensure proper and efficient use,

j) Perform continuous maintenance to extend economic life,

k) Ensure efficient use (reducing wastage),

1) Prevent outdatedness/obsoleteness,

m) Ensure immediate disposal to prevent depreciation,

n) Check latest supply at each entry,

o) Inform the accounting unit, and ensure agreement of records, 
p) Conduct regular inventory counts to identify any theft, wastage, depreciation or breakdown,

q) Ensure that ordering, receipt, protection and sales of goods, payments and collections, and accounting entries are carried out absolutely by different people,

r) Avoid ineffective advertising spending,

s) Ensure accurate and timely transfer of accounting information into the accounting environment.

The structure outlined above is the internal control structure relating to assets; and formation, running and maintenance thereof is one of the key duties of the management.

Also, measures such as preventing binding of business capital to unused fixed assets (sales/disposal/non-purchase), abolishing production at a loss, sales of fixed assets with exhausted economic life are also protective of assets, and all of these may be identified by an efficient use of the internal control structure. In particular, internal controls relating to retention and safeguarding of cash assets and precious papers are even more important, as they are more likely to be stolen, relocated or hidden and have higher value. Accordingly;

a) Those in charge of protection of cash, and those making payment and collection should be different people.

b) High amount of money/cheque should be kept at the cash register, and should be deposited to bank account at every day-end.

c) Those signing cheques/notes, making payments and transferring these transactions to the accounting environment should be different people.

d) Those making purchasing/sales decision, making collection/payment and recognizing these transactions should be different people.

e) Bearer cheques should be issued in high values.

f) If employees peforming follow-up of receivables also have the power to collect, they should be rotated.

g) Signing of high-value cheques and notes by business shareholders is a critical internal control measure.

h) Any deficiency identified with the internal controls should be immediately reported to the senior manager, and necessary measures should be taken.

Business assets are comprised by the assets owned and listed in the assets list of the business balance sheet. Assets or accounting records of the business may be used for unintended purposes. Any physical asset owned by the business may be eliminated or depreciated due to theft, breakage, rust, natural disaster or unintended use. 
In particular, high-value and easily-portable assets always run a high risk of theft. In businesses lacking a proper and organized inventory and safeguarding mechanism, reliable tracking of raw and other materials proves quite difficult.

To avoid unwanted situations concerning assets, the business management should establish a good internal control structure to continuously monitor practices.

To avoid all kinds of risks in businesses, it is critical to establish and continuously supervise/monitor the internal control unit.

In this sense, implementing the principles of separation of duties and authorization may constitute effective control measures. Likewise, regular physical monitoring and counting of the assets at places where they are protected are important in terms of protection of assets.

\section{Ensure Accuracy and Reliability of Information}

For those who take decision using business information, timely and accurate receipt of accounting information is highly critical. Otherwise, information which is not taken in a timely fashion or is inaccurate may lead to wrong or incorrect decisions. An example to this is the likelihood of loss arising from the decision to participate in the business / purchase shares without knowing accurate profitability and assets.

Reliability and accuracy of accounting information refers to accurate and timely transfer of accounting information to the accounting environment and inaccessibility thereof by unauthorized people.

Accounting information of a business should be protected with priority as they form the personality and essence of a business and represent numerical information as to its operations and essence. Accounting information are highly critical in terms of protecting competitive edge, financial strength, profitability and market possibilities of the business; and it is also highly critical to ensure inaccessibility of such information by unauthorized people except where mandatory (legal etc.).

Accuracy of financial information is important in every stage, including classification, summary, registration and reporting of such information. This information is transferred to the accounting environment in accordance with the generally-accepted accounting principles. The information transferred to the accounting environment is transformed into reporting at period-ends (as financial statements), providing information relating to financial standing and operating results of the business as well as other financial information. These financial statements are presented to the business management through internal reporting, and to the public and stakeholders through external reporting.

Business sheet shows the changes in a business' assets, liabilities and equities over a period, and income statement shows all 
expenses/spending/costs and revenues over a period. Both statements have a number of stakeholders. These include potential shareholders, potential creditors, management, shareholders, employees, professional organizations etc.

It is the management's duty to provide accurate and timely information to all stakeholders. Accurate financial statements require accurate information. And it is one of the key duties of the internal control to ensure timeliness and accurateness of information. Accurate and timely information ensured by the internal control also ensures effectiveness and efficiency of business operations. If the internal control provides timely and accurate information, comparisons with the costs assumed will be as much accurate and real. Decreased costs may lead to higher effectiveness and efficiency. This way, incorrect and wrong decisions as well as waste of resources will be avoided. In other words, errors, frauds and other risks may be pre-emptively prevented/mitigated.

One of the key purposes expected of the internal control is to provide accurate, reliable and timely receipt of information from the business' accounting environment and other sources.

Reliability of this information is highly critical for those who will take decisions related to the business. Formation of an internal control structure at a business and constant supervision and monitoring of its effectiveness/practices is directly relevant to / has direct impact on elimination/mitigation of potential errors, frauds and other weaknesses.

To summarize, the most important tool in preventing risks at businesses is the internal control and effective implementation thereof. The business management is directly responsible for any potential error, fraud, corruption and related losses which may arise in case where the internal control structure and practices do not exist.

Efficient and effective use of business resources through effectively implemented internal controls will improve productivity and eliminate unexpected and unnecessary increase in costs.

Effectiveness in operations refers to execution of a business' operations in accordance with determined business policies, targets, plans and the legislation. The internal control structure has direct impact on improving effectiveness in operations.

Also, the responsibility to ensure execution of business operations in accordance with the policies, plans and the legislation rests with the business management. Improving efficiency of business operations and ensuring alignment of operations with budgetary and managerial policies may only be achieved by developing and effectively implementing the internal control structure (Aksoy, 2006). 


\section{Effective and Efficient Use of Business Resources}

Establishment and implementation of an internal control structure at a business will ensure proper use of all business resources, prevent unnecessary increase in costs as well as delay in production-sales, purchasing-entry, salesentry processes, leading to increased effectiveness and efficiency in business operations. It will be easier to perform operations effectively and compare operating results with budgetary and estimated results. This, in turn, will document the level of attainment of goals, i.e. level of effectiveness and efficiency.

Efficient use of resources translates into the amount of consumed resources not exceeding the amount of utility (efficiency) attained. If the goal (purpose) is achieved with accurate, timely and minimal use of resources, this will mean attainment of efficiency. Effectiveness refers to level of attainment of planned goals and purposes. Attaining planned production amount stands an example to effectiveness.

Therefore, an acceptable level of deviation from planned and realized goals means attainment of effectiveness (Erdoğan, 2009).

Another method in improving internal control efficiency is to continuously inform employees on importance of internal control. To summarize; attaining goals with proper, timely and minimal use of resources means efficiency, while effectiveness (being economical/prudent) means planned costs turning out to be lower than realized costs (Kepekçi, 2004).

\section{Ensure Attainment of Determined Goals and Purposes}

Implementation of the internal control structure corresponds to its effectiveness. Attainment of goals by the business management means achievement of an effective internal control. If inventories are protected, costs are reduced through effectiveness, and achieved and planned targets are comparable, every person performs their duty, timely access to information under authorization scheme is possible, and timely reporting can be made to the management, then the internal control is considered to achieve its goals. This, in turn, corresponds to achievement of internal control goals.

The more capable the internal control structure is to prevent or avoid potential risks, the more effective the business is with their operations. Mitigating and preventing risks through concentration of internal control measures is important, particularly for risky areas. In case of identification of risks (theft etc.) in collections and pays, for instance, higher concentration should be placed on controls relating to outflows from inventory, collections and transfers to the accounting environment. In case of a higher-than-expected rate of wastage, wastage or deficiency in inventories, places where inventories are protected should be kept in better conditions, outdated or obsolete inventories should be continuously monitored, inflows and outflows should be 
entered to inventory cards on timely basis, and physical inventory should be taken with sufficiently short intervals. Also, it is recommendable to monitor whether or not values of assets are protected.

As all these practices are attainable through internal control, the internal control will provide the management with necessary information as to:

a) Costs/efficiency of operations,

b) Quality of inventory at the warehouse,

c) Quantity and amount of inventory at the warehouse,

d) Comparison of achieved and planned targets and deviation,

e) Whether or not the principle of separation of duties is followed,

f) Reliability and timeliness of information,

g) Whether or not there is unauthorized access to resources.

\section{Conclusion}

An effective internal control structure is a crucial element in ensuring efficiency, profitability and sustainability across businesses. An effective control structure is the key to success desired/aimed for a business. It should be noted that building an internal control structure alone will not prove sufficient for success. Internal control structure should, first of all, employ a comprehensive and collaborative approach that addresses all level of employees, including executives first, and then lower levels. Measures required to ensure effectiveness and efficiency of the system should be taken. Continuous performance of activities, identification of potential risks as well as development of suggested solutions on a timely manner is critical to ensure effectiveness of the system. A well-designed and well-practiced internal control structure will contribute to the business in terms of reliability, compliance with regulations, financial reporting and efficiency in operational aspects. Ensuring effective design and practice of an internal control system will not only minimize fraudulence and misconduct across the business, but will also add value in terms of "growth" and "sustainability of business" in particular.

\section{References:}

1. Arthur W.Holmes and Wayne S.Overmyner; "Auditing”,N:1,Ontario, 1975.

2. Celal Kepekçi, Bağımsız Denetim, Avcıol Basım Yayın, İstanbul, 2004.

3. COSO; Enterprise Risk Management Integrated Framework, 2004.

4. Çetin ÖZBEK, İç Denetim, Kurumsal Yönetim, Risk Yönetimi, İç Kontrol, Türkiye İç Denetim Ens. Yayınları, No:3, Cilt.I, İstanbul, 2012. 
5. Ersin Güredin, Denetim ve Güvence Hizmetleri, İstanbul, 2010.

6. Hasan Gürbüz, Muhasebe Denetimi, Bilim Teknik Yayınevi,İstanbul, 1995.

7. Hasan Türedi, Denetim, Trabzon, 2007

8. Hasan Türedi, Muhasebe Denetimi Ders Notları, İstanbul, 2013.

9. IFAC, Uluslararas1 Muhasebeciler Federasyonu Uluslararası Denetim ve Güvence Standartları, 2013.

10. International Standards of Auditing, ISA315.

11. John W. Cook and Gary, M. Winkle, Auditing :Philosophy and Technique, 2.Ed. Houghton Mittlin Company, Boston, 1980.

12. Sermaye Piyasası Kurulu (SPK); Sermaye piyasasında Bağımsız Denetim Standartları Hakkında Tebliğ, Seri:X, No:22.

13. Simay Erdoğan, İç Kontrol Sistemi, Kamu İktisadi Teşebbüsleri İçin İç Kontrol Modeli Önerisi, DPT Yayını, Ankara, 2009.

14. Tamer Aksoy, Basel II ve İç Kontrol,Ankara S.M.M. Odası Yayını, Yayın No:53, Ankara, 2007.

15. Tamer Aksoy, Tüm Yönleriyle Denetim, Cilt:, Yetkin Yayınları, Ankara, 2006.

16. The IIA Research Foundation -Türkiye İç Denetim Enstitüsü(TİDE), Uluslararası Denetim Standartları- Msleki Uygulama Çerçevesi- 2004.

17. Walter B.Melgs and Robert F.Meigs, Accounting The Basis for Business Decision, New York, 1988. 